\title{
Patterns and Links in Satyajit Ray's Fairytale Trilogy
}

\author{
By Bansari Mitra \\ Spring 2014 Issue of KINEMA

\section{A TRIUMVIRATE: KALEIDOSCOPIC PATTERNS AND THEMATIC LINKS IN SATYA- JIT RAY'S FAIRYTALE TRILOGY}

\begin{abstract}
This fantasy trilogy demonstrates that the fairy tale is a very fluid form of narrative. It travels from village to town to city, and from country to country, thereby gaining and losing some outstanding characteristics. Magic always prevails, the most distinguishing feature. It can be used for various purposes because its fantasy lends itself to various forms like allegory, satire, parody, symbolism and even realism, the most opposing genre. We see how the progress of the films and the collaboration of several Ray family members make this trilogy so complex, from fairy tale and slapstick comedy to contemporaneous political satire and necromancy.
\end{abstract}

I

Film critic and biographer Marie Seton observes in her well-known biography of Satyajit Ray, the greatest Indian film director: "He was occupied with thoughts of a film based on his grandfather Upendrakishore's fantasy, Goupi Gyne Bacha. Sandip had been complaining that his papa's films were too tragic and he wanted a film to make him laugh." (259) Perhaps it is to Sandip Ray that we are indebted for the fairytale trilogy of Goopy Gyne Bagha Byne. He not only demanded a funny film from his father, but also directed the last one in the trilogy, for which Satyajit had written the story and the songs. It is amazing to see how all the three tales are put together by the three generations and created out of fantasy, music and dance, a unique mosaic.

Upendrakishore Ray was a great collector of folktales as his Tuntunir Boi reveals. He was a master storyteller and painter; his grandson inherited both talents as well as his fantastic imagination. In this essay, the members of the Ray family who are studied are Upendrakishore, Satyajit and Sandip - grandfather, grandson and great grandson, who put together the trilogy, Goopy Gyne Bagha Byne (The Adventures of Goopy and Bagha, 1968), Hirak Rajar Deshe (The Kingdom of Diamonds, 1980) and Goopy Bagha Phire Elo (The Return of Goopy and Bagha, 1991).

Satyajit loved making fantasies. Although many of his films are distinguished by stark realism, there is a streak in him that indulged in fantasies, something that he inherited from his father and grandfather. It is very evident in his science fiction and supernatural tales. He is very versatile. All kinds of things appealed to him: art, music, film, photography, acting and writing. It is the method of narration that we will examine in the three movies that form a link together, like a design. There are three aspects of the films that we wish to examine: the legacy of folklore, the songs and the humour. We will also see how a kaleidoscopic pattern emerges in each film when there is a shaking up, almost like beads that are put together, taken apart and again put together in a child's toy. This trilogy is meant for children but it also appeals to adults. We note that in each film, in spite of the many differences, some key characters and motifs persist, thus holding it all together in a closely knit trilogy.

The ancestral background invariably comes to our minds because the Ray family of Calcutta is distinguished by three giants: Upendrakishore, Sukumar and Satyajit. Seton says:

Two qualities strongly developed in Satyajit's father and grandfather find renewed expression in him: humor is woven as a natural thread through the texture of all Ray's films . . . grandfather's story Goupi Gyne Bacha, as expanded by Satyajit, carries the qualities of fantasy and the comic on to a more complex level. Ostensibly a fairy tale, the dual heroes, two young musicians, bring, by their tricks, an end to the disease of the ages - war. (298)

It is these two qualities in Satyajit's movies that have not been studied much by western critics. This dearth of criticism of Ray as a fantasist and humorist does little justice to the legacy that he inherited from his family. Partly it is because the family members used different media for their expression of art: Upendrakishore was a painter, musician and storyteller. His son, Sukumar, the father of Satyajit, was an illustrator and writer 
of nonsense verse and stories for children. Satyajit, aside from being a writer of children's stories and songs, was first and foremost a film director. In this prowess he differed from his father and grandfather, and as a result he is more famous in the western world than his ancestors. However, two elements that are shared by all three are fantasy and versatility, two outstanding family characteristics that are manifest in the trilogy, showing us the richness of Satyajit's legacy.

It is necessary to study these two elements in Satyajit's art because the picture that is presented to the West through a repertoire of his films is often rather limited and even a bit distorted. We forget the other Satyajit, whose witty and fanciful imagination did not get its due in the West because even in the 90s, only a few of his award-winning films were shown in New York City or Los Angeles. The American film scholar Steve Vineberg complains:

As far as I can tell, Ray is the greatest living filmmaker, but it's almost impossible for Americans to see more than a handful of his movies. Available on video are the trilogy, made between 1955 and 1959 . . . Over a period of nearly two decades, I've managed to see a dozen others, mostly at universities or cultural centers. (33)

The sparsity of film festivals and retrospectives only tends to present an image of Satyajit Ray as a gloomy, tragic filmmaker who did not have a light side to his character. The Goopy Gyne trilogy is scarcely known in the West. A "children's film," especially a funny one, tends to be dismissed rather easily. As Eric Barnouw observes about Goopy Gyne Bagha Byne:

Very successful in India, it has been considered - perhaps mistakenly - less translatable than Ray's more serious films. This attitude, applied to other comedies also, has tended to give Ray a more somber image outside Bengal than he is at home. (237)

We can attempt to dispel this somberness of Ray's image, in India and beyond.

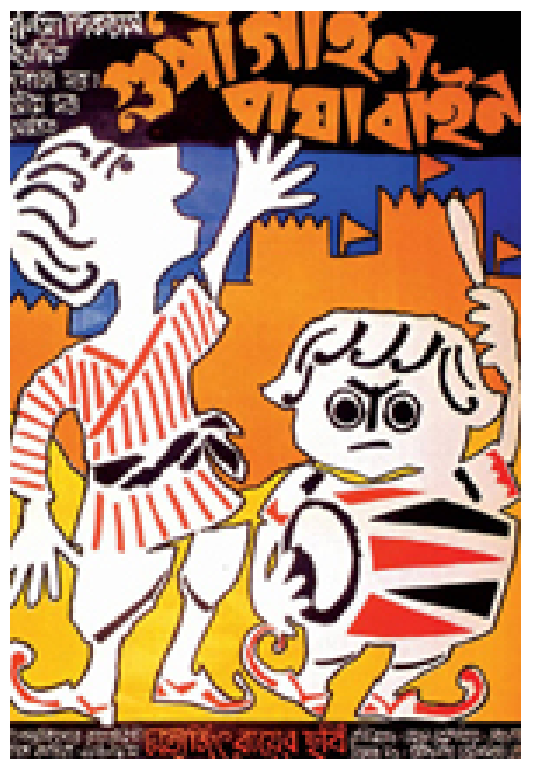

Figure 1: Goopy Gyne Bagha Byne poster designed by Satyajit Ray

\section{II}

Satyajit Ray tended to adapt classic works by Bengali writers for the plots of his films. His Goopy Gyne trilogy is an exception because its source is folklore, a rather crude form of art that evolved in the villages. Folklore, as we know, is something that constitutes the great oral tradition of rural people. As legends travel from village to village, they get embellished, expanded, varied and transformed. As the American film historian Jack Zipes points out:

The literary fairy tale has evolved from the stories of the oral tradition, piece by piece in a 
process of incremental adaptation, generation by generation in different cultures of people who crossfertilized the oral tales with literary tastes and disseminated them. If we consider that tales are mentally and physically conceived by human beings as material products of culture, then it is possible to analyse how special forms of telling originated as species or what literary critics call genres. (3)

It is genres that we must study when we examine this trilogy. We will see how genres are redefined when the oral tale becomes a written one. The folk tale that gets transcribed into a written form is modified to suit the taste of literary circles of urban society. In Bengal, the coarse village lore was refined by collectors like Upendrakishore Ray, in order to cater to a select literary audience: urban children and adolescents. In his fairytale trilogy that stems from the tale of his grandfather, Satyajit modernizes themes from ancient folktales that have flourished in the obscure villages for centuries.

The fairy tale is a very fluid form of narrative that travels from village to town, town to city, country to country, thereby gaining and losing some outstanding characteristics. Magic is one feature that persists, and that constitutes the charm of the fairy tale. It can be used for various purposes because its fantasy lends itself to various forms like allegory, satire, parody, symbolism and even realism. In the Goopy Gyne trilogy also, the predominant characteristic is fantasy and it is used to create various kinds of genres like fairy tale, slapstick comedy, contemporaneous political satire and necromancy.

At first, when Satyajit put the project in motion, the task was fairly simple. A popular tale, well-known in the Bengali circles, could be dramatized without making major changes. All the folkloric elements like winning by a trick, or buffoons providing entertainment, paved the way for success. Moreover, the pairing of Goopy and Bagha by two new actors who form a duo as memorable as Laurel and Hardy, really appealed to the public. But with the progress of the films, we see that a major shift takes place when Satyajit switches to political satire.

Political satire, a sophisticated literary genre can be masked by the fairy tale form simply because the fantasy makes impossible things happen and resolves disasters into quick, happy endings. Moreover, satire, a very incisive weapon can be thinly disguised as witty allusion. However, what lurks under cover of laughter and fun is really an unmitigated exposure of vice and corruption in political leaders. Satyajit, through the lens of a child's tale, makes the theme rather obscure for the younger audience, but the adults do not miss its meaning. Thus Hirak Rajar Deshe becomes more complicated than an ordinary tale of adventure and fun.

It is the final tale in the trilogy, Goopy Bagha Phire Elo that strikes the most ominous note. There are horrible Tantric rituals, black magic and unholy powers masked by saffron-robed disguises that make this tale the darkest of the three. One feels that the director's vision has darkened, not only due to loss of vigour or enthusiasm but also due to disillusionment, ill-health and premonitions of death. Seton noted that:

As a little child he had sensed an affinity with his dying father; once when we were discussing Indian intimacy with the process of dying, Satyajit suddenly said that throughout his youth his mother had protected him from this familiarity with death because at three he had been so upset by the death of his father. (296)

This premonition of death culminates in the last film as a deeply gloomy vision. It reveals a loss of joy and an aging process that cannot be reversed; and a desperate attempt to cling to youthfulness leads to a catastrophe. In this context, the gothic, the final genre that Satyajit adopts, becomes especially relevant.

The gothic is known to rouse terror in our hearts, not simply as ghost tales but as something ominous, dealing with supernatural and occult powers that seem to create a vision of evil that might be unsuitable for a children's film. However, as the final film that completes the circle, it fits into the scheme, not merely because of the recurrent motifs that knit the stories together but also because the young boys, although imprisoned and victimized, strike a positive note. It is that positive note that finally lifts the dark mood of the film and makes it more appealing for the audience.

Lastly, it is the fairy tale that proves to be a perfect vehicle of expression for this trilogy because its fluidity of form becomes ideal for the handling of the themes that are varied, even though many of the actors remain the same. Its adaptability proves to be ideal for the quality that we have noted in the film director's talent: 
versatility.

\section{III}

Upendrakishore is a great folklorist and storyteller, but his art consists more in retelling than in creating stories. Goopy Gyne and Bagha Byne is one of his rare, original stories and it is marked by the Ray family storytelling characteristics: hilarious situations, clownish characters, genial wit and humour. As we examine the plot of his story closely, we find there are many traditional themes that he borrows from folklore: rags to riches, blessings of gods and triumphs of tricksters.

It would be convenient to outline the plot of the original story. Goopy and Bagha, two musicians play so vilely that they are driven out of their villages. However, their song pleases the ghosts and they are granted three boons: a bag supplying all kinds of food and clothing, magic shoes transporting them everywhere and most important of all, the ability to play music entrancingly. Thus they are patronized by a good king and when his kingdom is threatened by another, they manage with their unique abilities to defeat the usurper. They marry the king's two daughters and live happily ever after.

In Upendrakishore's tale we can find all the common folkloric elements like the luck of vagabonds marrying princesses, or the gift of magical bags and shoes, but what makes it a unique tale of adventure is not just the thrill of danger but the hilarious situations that occur because of the boons that are granted by ghosts. True to the tradition of fairy tales, the village buffoons keep blundering throughout their way. They are also mistaken as gods or ghosts when they fly to distant kingdoms or rain down sweets to devotees at a temple or fly with the kidnapped king. As in fairy tales, violence merely causes amusement, as when a police chief and his guards are burnt alive while listening entranced to their song. It only enhances the comedy and makes it an original tale that is spun out of raw materials like crude village lore and well-worn themes. For instance, the fact that ghosts like music detested by humans is a familiar occurrence in folklore and in this story it turns out to be hilarious. In Satyajit's version however, it is not so simple because it is used with a great deal of irony.

Satyajit, in his adaptation, keeps the frame of the tale intact, but omits and changes some details so that we are reminded of the patterns in the kaleidoscope that keep changing, rearranging and transforming the pictures. There are some minor details that are changed: the King of Shundi, the villain in the original story, is the good king in the film. It is Goopy who is the buffoon in the film instead of Bagha. Also, they only need to clap their hands together to get food and clothing instead of a magic bag; and there is no violent scene of the police chief being burned alive as that would be unsuitable for a children's film.

The first film met with outstanding success because of the two highly comic characters and the satiric portraiture of kings and courtiers. There are darker undertones that are often kept at bay by the humour, but they keep recurring nonetheless, especially because as a theme, hunger and want knit the film scenes together. There are good and bad kings and they often alternate. Although it is often a symmetrical pattern, good kings alternating with bad kings, we notice that the underlying theme is that of the commoner pitted against the king, and the wealthy keeping food away from hungry mouths. It really leads to oppression of the masses.

Throughout the film, we see this oppression of masses that makes the theme far more complex than a simple fairy tale. In folktales too, there are themes of want and hunger that are nonetheless resolved into happy endings, especially with the aid of magical bags. Even though Satyajit adopts this solution from his grandfather's tale, in a way making it end even before the story begins, we see that the hungry villagers highlight the theme of oppression. In fact, the director uses this story for a different purpose other than merely entertaining the audience with a film that is full of song and dance. Even his songs are very different from the traditional ones of Hindi and Bengali films, because they convey a profound message through Goopy's warning to the soldiers about the futility of war. It culminates in the song: "You can take beating if your stomach's full they say/this lot looks like they'll die of empty stomachs on the way, marching off to war."

Thus we see that the fairy tale is a thin disguise for preaching a message to the audience; and as such, the film is very relevant and even contemporary though it was made four decades ago. As we watch the film, we discover new meanings and can relate it to our own troubled times when so many nations are dealing with 
the impact of costly and useless wars. As author Ben Nyce observes:

More than a fairy tale, Goopy and Bagha is also a film which says to children (and all of us) that warfare and aggression are wrong and that we should beware of being manipulated into it by misguided and unscrupulous leaders. (117)

The message continues to warn us, thus making it far more significant than an ordinary children's film. We see how this pattern persists in the other two, showing us what lessons are taught by these adaptations from folktales. All the films are linked by the songs and dances of this pair.

Barnouw describes the first film as "rollicking, phantasmagoric": Its creatures included demons, wizards, animals, and people and its climax involved efforts to prevent a war. Cartoons by Ray joyfully set the mood. Its dances and lyrics had elements of the Indian song and dance genre, and its cast of characters suggested the mythological, but all in a different and refreshing context.

Satyajit Ray may have borrowed elements from the traditional Indian film, but he radically revises those elements by creating this new kind of musical. Goopy and Bagha are mythological characters of the Indian screen mainly because they are well-beloved by their audience.

The grand climax in the film is the ghost dance. It is a fusion of so many different and even opposing elements, lights and shadows, princes and peasants, ghosts and humans, forests and blank spaces, fights and friendly overtures, stills and movements, and rags and robes. And there is the swordplay, evoking the central conflict between the rich and poor in the film, where men armed with sticks are defeated by soldiers with superior weapons like swords and clubs.

It is also remarkable that the very first film of the series, shot in black and white, is the lightest of them all. Nyce says: "Ray wanted to shoot the whole film in colour but the political and economic crisis in India in 1966/67 (including a strike in the Bengali film industry by workers protesting the invasion of cheap Hindi films) prevented it." (116) However, this shortage of funds turned out to be a real blessing because the ghost dance would have been totally ineffective in colour.

Like the ghost dance, we feel the plot's motion is built on a principle of opposites, the good king versus the bad king. One evil king banishes the protagonist to the forest. A ghost king saves him and here is a real irony - a ghost is better than a human. Shundi's good king patronizes the lads but Halla's bad king threatens to destroy them. Goopy and Bagha must use their gifts wisely in order to succeed; like the message Goopy sends out that we are misled by evil leaders into murdering our brothers.

It is in fact this message, concealed beneath the naivety of the two protagonists that makes us aware of the purpose of the film: indicating the futility of war. Thus we become aware of Ray's ideological perspective, something that has been neglected by critics. As Chandak Sengoopta observes:

Ray in other words, continues to be portrayed as the gentle humanist, a superlative purveyor of nuance and emotional depth but an artist whose ideological position is of no great importance. It is certainly 14 true that Ray always denied that he made films to change the world and unlike his Bengali contemporaries Mrinal Sen or Ritwik Ghatak he never showed any interest in Marxism. But that should not obscure the simple fact that Ray, in his own way, was as much an ideological artist as his peers. (16)

His stance in Goopy Gyne, imparting the message about warfare, hunger and poverty, certainly proves this fact.

IV

Hirak Rajar Deshe, the next film, is especially remarkable because it is the only film in the trilogy of which Satyajit is the sole auteur, though some critics like Andrew Robinson say it shows influences from Sukumar Ray's works:

Goopy and Bagha released the pent-up love of fantasy in Satyajit Ray that is given free rein in his grandfather's and father's work, and the love of singing and song-composing which was so strong in his grandfather. Its inspiration comes from Upendrakishore, while that of The Kingdom of 


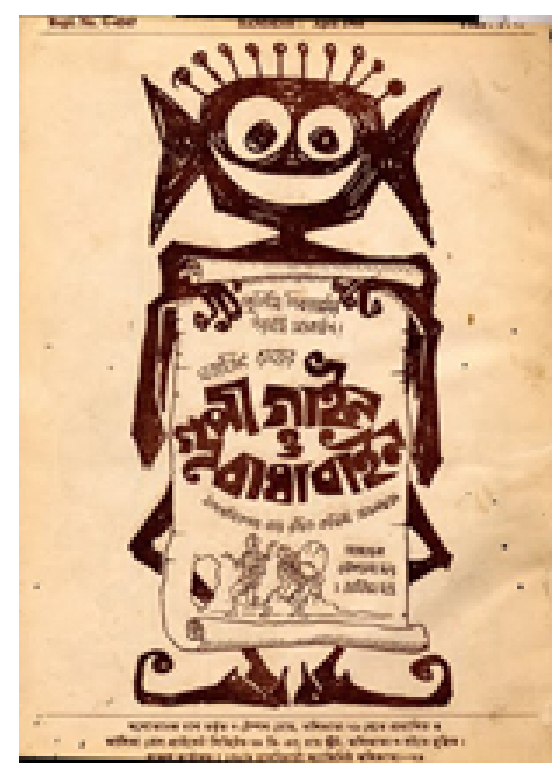

Figure 2: Satyajit Ray's poster for Goopy Gyne Bagha Byne

Diamonds derives more from Sukumar - its word play and juggling of ideas is much akin to his plays. (183)

The influence is really quite slight. There are perhaps a few strains from Sukumar's nonsense verse, like "The Rule of Twenty-One":

In Shiva's homeland, the rules are quite strange as I can truly attest.

If someone slips, and falls by err, police come by to arrest.

Your ordeal continues inside of a court room.

When judges are ready to fine you a fortune.

Twenty-one rupees is the fine you must pay.

It reminds us of some of the characters in the film, especially the downtrodden ones, who are walking through a minefield; one false step or any question regarding the king's policy can lead to imprisonment and death. It is a satire aimed at Indira Gandhi and her dictatorial policies during the emergency period in India that led to widespread arrest of the political leaders, the banning of controversial plays and various excesses committed by supporters of Gandhi and her associates. Thus we see that the real appeal of this film lies in being so contemporary, because it was filmed during the emergency. Nyce declares:

It's an angry response to the emergency decreed by Indira Gandhi in 1975-77, in which censorship and police control were severe and intolerable to most Indian intellectuals. The anger is barely masked by the entertainment. In this way, presumably, the film could get by the government censors. (176)

The fairy tale really serves a purpose here in masking the savage satire that Satyajit aims at the Education Minister when he makes the pupils of a village school recite a parody of well-known proverbs: "He who learns dies of hunger - there is no limit of knowledge - so it is useless to know." In schools, colleges and universities, many students were punished during the emergency for protesting against the regime; and this is revealed in the struggle that Udayan Pandit, the village schoolmaster carries on, like a revolutionary, with the help of his pupils and Goopy and Bagha.

Certain scenes of the film reflect exactly what occurred in Delhi during emergency, when the slums near Jama Masjid were bulldozed to the ground by the police and poor people were driven out of the only homes they had. When we see the ramshackle huts of the villagers being razed, or Udayan Pandit's books being burned, we are reminded of these events. Thus new themes are introduced to enrich the design of this trilogy, 
even though the actors are unchanged. When the film opens with the heroes dressed in royal robes, we are misled into thinking that this is a more gorgeous and therefore more cheerful film, because the sets are richer, and the film is shot in colour, in one of the oldest palaces in Rajasthan. Satyajit Ray recalls an amusing encounter in his book, Our Films, Their Films:

It was hard to believe one was sitting in conference with the Maharaja of Jailsamer, the oldest fortress town in western Rajasthan... Would the present king resist an encroachment by a film company? I wondered.

"But why Jaisalmer?" asked the Maharaja. A moot question uttered in the flattest of drawls. Drink? Lethargy?... The lusterless eyes beneath the drooping lids revealed nothing.

I said I had chosen Jaisalmer because (a) it was a most dramatic location perfectly answering the needs of our story and (b) it has not been used by any other feature film makers before. (76)

Fortunately, the Maharajah consented, because he was charmed by the music and all the Goopy Gyne films were shot in this location. However, in spite of the splendid sets and rich colours, Hirak is a much darker film than the preceding one, because there is a war against evil that goes on relentlessly.

We see that in this film the director's vision has darkened. The nostalgic vision of youth that ensues from his aging and illness is progressive in this trilogy, so that in the end very few elements of joy remain. The original tale by Upendrakishore is a straightforward fairy tale, combining elements of slapstick humour with the enchantment of children's tales. Satyajit, in spite of the dark undertones of his first film, like the futility of war and the recurring picture of starvation, preserves the fairytale form intact. Hirak is more of a political satire and therefore more complex.

In Hirak, Goopy and Bagha are bored in the palace. They go forth and find the people of a kingdom under the yoke of tyranny. With the help of their magical powers, they overthrow the tyrannical king and restore peace to the kingdom. It is clear that all the three films are bound together with three recurring motifs: kings engaged in war, hunger and poverty and supernatural elements. What is interesting is that the two heroes change. They do not remain static throughout the trilogy.

The important theme in Hirak is the passage of time. While the framing songs start as apt expositions, telling us about what has happened during the last ten years, how the heroes are married and fathers of two sons, there is still that easy camaraderie that is so charming. Those who have not seen the earlier film are also told how they achieved this success. Moreover, they plant the seeds of the plot of the next film in the concluding song, announcing that they will come back. Structurally and thematically, the two last films are especially linked by the framing songs that occur at the beginning and end of the films. At the end of the last film, Goopy and Bagha request that we never forget them, quite unnecessarily, because no duo in Bengali films has occupied such a prominent place in the audience's long term memory. It is not just because they are so different from the ones in Satyajit's Ray's sad stories, but because they strike a chord in us, children and old alike, and make us wish to launch forth in adventures.

In the movies, true adventure tales, women are left out. In western and eastern fairy tales, princesses are passive and it is the prince who kills the giant. As Andrea Dworkin points out in Woman Hating, Snow White and Sleeping Beauty are entirely passive, lying in a deathlike swoon, waiting for their princes to rescue them. It is always the prince who sails beyond seven seas to deliver the princess. In this case however, it is not the princess but an oppressed people that these two princes in disguise must deliver. It is here that a new and refreshing twist to the traditional fairy tale plot is added, along with the poking of fun at political leaders.

In Hirak, Goopy and Bagha must use their talents for greater purpose by delivering people in other kingdoms from evil. This theme becomes more and more crucial in the trilogy. While traditional subjects such as warfare, poverty and starvation are characteristic in the first part, the fairy tales in Hirak and Goopy Bagha are more modern, more contemporary. They contain more ominous themes, including mesmerism, necromancy and brainwashing. The traditional fairy tale, as it has evolved through the ages, usually involves key themes such as battle and hunger - the prince could best distinguish himself in battle with dragons. However, poverty, the dubious soil from which the rich tales of fantasy sprang, becomes menacing in the 
rhymed couplets that are used to indoctrinate poor peasants.

Even the happy-hearted tales of Goopy and Bagha are no exception. Although there is wish fulfilment, eradication of exploitation and tyranny, and the alleviation of poverty, the lot of the very poor becomes more ominous in the last two tales. Although the tyranny is more subtle and there is no threat of languishing in prison or beheading, there is something more terrible and damaging, that which affects the mind brainwashing. This is where the second and third parts are in contrast to the first, where the wicked characters are never truly punished. The evil minister in Goopy Gyne for example, is only deprived of his pot of sweets and injured in the stampede. As Pauline Kael observes:

The concept of humanity is so strong in Ray's films that a man who functioned as a villain could only be a limitation of vision, a defect, an intrusion of melodrama in a work of art which seeks to illuminate experience and help us feel ... We see his characters not in terms of good or bad but as we see ourselves, in terms of failures and weaknesses and strength. (63)

The King of Halla is only a weak character manipulated by his minister and magician. At the end, he is received with open arms by the King of Shundi. In Hirak however, the evil king is really punished; he is the victim of his own weapon that turns against him. The brainwashing machine finally makes him such a zombie that he joins the crowd in pulling down his own statue. Thus the king is brainwashed, but Goopy and Bagha claim that this is only a form of exorcism; they declare in their farewell song that with the help of the Ghost King they drive away other people's ghosts. They also bribe people, especially the wizard, to turn against the king and his ministers just as earlier we had seen the king controlling the courtiers with bribes. Thus the ominous question surfaces, who are the good and bad characters, if the methods adopted by each show no difference?

Even worse is the really ominous note struck by the fact that there are always bad kings versus good kings who are often the two sides of a coin, because the same actor plays the parts of the kings of Shundi and Halla. In every tale this pattern persists, along with ghosts and tigers, tyrants and sycophantic courtiers, aristocrats and villagers.

In each film, Goopy and Bagha are being temporarily thrown into inaction through imprisonment so that in the end they escape by means of bribes. In the first film, such is the hunger of the guard that he lets them escape in order to have, after a long time, a good meal. In the same way, in the next film, it only takes a few diamonds to win the scientist over to the good side. The scientist, true to the persistent pattern in the films, is only another version of Barfi, the evil magician in the first film. Like Barfi, who has some good powers, such as curing people of dumbness, the scientist can also make paper flowers that smell heavenly. We see how these themes are continued in the last and the darkest of the films, Goopy Bagha Phire Elo.

\section{V}

Many years have passed. Goopy and Bagha take one last journey to deliver a kingdom from evil, this time from a necromancer, Brahmananda Acharya, who wants to be immortal so he hypnotizes people, especially young boys. He makes a false promise to Goopy and Bagha that he will make them young again if they steal jewels for him. Goopy and Bagha are tempted but return the jewels they have stolen. A boy called Kanu kills Brahmananda and the boys are saved.

As we see, the plot has become more twisted. In the earlier film, satire and songs are not exactly lighthearted, but there is still some good fun, but here it is truly ominous. In many ways themes are repeated from the first and second film: the young boys in school, the good king and the magic shoes. But there is the necromancer who is much worse than Barfi the evil magician or the scientist wizard. He is evil incarnate because he lies, pursues black arts and wishes to defy laws of nature. There are again the framing songs, the appearance of the Ghost King, in the same guise. The films are tightly knit because of the two unbeatable heroes, even though they span twenty years. However, it is the character of this pair that has changed and that has the most ominous repercussions. The passage of time is the theme that really casts a shadow over this film, in a much darker way than in the preceding one.

This particular film is directed by Sandip, the only son and inheritor of Satyajit. Satyajit could not complete the making of this film due to illness, but he wrote the story and the songs for it. Sandip, trained by his father, has followed the tradition and added his own touch to this trilogy, thereby completing the circle. And 
we see his father's touches everywhere, not only in the script and songs; it is fortunate that Satyajit left such a legacy behind for his son and for us as well.

As has been observed before, the real change is in Goopy and Bagha. When we first saw these two village buffoons, they were in rags but their jauntiness instantly won our hearts. Hirak begins where they left off in the final scene of Goopy Gyne. They dress in royal robes, thereby becoming princes of the realm; and when the next film opens, they are dressed that way. However, their characters are unchanged, even though they are ten years older. In fact, the song that declares: "No, no, no more wastage of time" is just as vital and effervescent as the one they sing to celebrate the three boons in the earlier film. We love them not just because they are simple hearted village lads but because of their buffoonery; that is what makes the films so 20 hilarious. Even the satire in Hirak fails to subdue the hilarity; but in Goopy Bagha, there is hardly any such laughter.

Above all, these two characters have become greedy. They are prepared to sell their souls to the devil in order to gain twenty more years of life. That in itself is the most frightening aspect of the characters that we see, perhaps even more frightening than the greedy necromancer, a robber turned holy man who, under his saffron robes, hides ruthlessness and vice. In fact the Macbeth-like warning at the beginning of the plot that a boy named Vikram will kill him makes it a much darker story.

The first film is a humorous fairy tale, the second a political satire and the third one is a mystery; except that the two detectives are themselves deluded and corrupted by the villain and that is rather a surprise. The Ghost King saves them by telling them that aging is not bad because they gain experience and respect, but the final forgiveness they gain comes as a far too simple solution. However, it is the character of Kanu the little village boy, whose real name is Vikram, that seems to be the most redeeming feature in the story. The little boy, so pure and innocent, teaches adults that stealing is wrong. While there is a fine sense of irony here, ultimately the message in the film seems to be that only the pure in heart will win because they are clothed in the splendour of truth and valour and innocence.

It is remarkable the way in which the villain is destroyed. In the other two films, the villain's punishment is too slight - the minister only loses his pot of sweets. And in Hirak, the king is justly punished by his own weapon of brainwashing so he is converted from a tyrant to a harmless fellow, a victim of his own infamous plot. However, such comical or light punishments are not to be dealt out to the necromancer. He has committed the worst of crimes and mesmerized and stunned innocent young children. He has committed many murders to get the jewels he wanted. Moreover, he has made false promises to Goopy and Bagha and corrupted them as well. Thus he burns alive when he comes face to face with Kanu/Vikram. Then the boys are released and Goopy and Bagha also return to the straight and narrow path of virtue.

In fact, it is only the timely intervention of the Ghost King that saves them when they fall asleep due to drugs administered by Brahmananda. The vision has darkened to the extent that our heroes, real simpletons, are no more our heroes. Although they restore the jewels to their owners, obey the Ghost King and beg forgiveness, the one thing that remains clear is that they have changed. Although they insist that they only do this to play a trick on the necromancer, and their real aim is to deliver the boy prisoners, we know that the real reason why they do it is to gain back their youth. And that brings us back to the thematic links we first examined at the beginning.

We know that the passage of time is a crucial theme in this trilogy and with the aid of just one song we can catch up with the story so it is not repetitive. And the structure of the three films with common motives and characters helps as well. However, what is remarkable is that the first one, done in black and white because Satyajit could not afford to shoot in colour, is the most light-hearted of them all; even the second film is relatively cheerful. Although brainwashing is a more devastating weapon than battle cries, the two protagonists are untouched; they are only concerned about losing their energy. In the final film however, we know that things have changed, not for better but for worse. In fact the only person who seems to be unchanged is the Ghost King, who, because he is already dead, cannot die or change. He never had to admonish the two before, but only wanted to bestow gifts upon them.

As the trilogy progresses, the plot tightens; Upendrakishore's story is loosely knit and because Satyajit follows the plot closely, the film is loose too, with varieties of scenes, shifting from village to Halla to Shundi; 
and like Halla that they deliver from evil, they must deliver Hirak and Anandapur. It is rather comical to see that they really act like the detective and his assistant, a pair, except that no-one leads. They are completely equal and rule together the kingdom of Shundi in perfect harmony, in a very fairytale-like way. However, in the last film few other elements of the fairy tale persist except the Ghost King and Goopy and Bagha's magical powers. Everything else is marked by necromancy. Even the evil spirit, the voice that speaks like the three witches in Macbeth, reminds us more of occult literature, unlike the Ghost King who is merely supernatural; it evokes powers that consist of horrible rituals like human sacrifice. That element combined with the mystery, really makes us feel it is more gothic than fairy tale.

Thus we find a trajectory from fairy tale to political satire to mystery/gothic and though many of the characters are the same, especially village boys or elders or the police force, the real essence of the story changes. Buffoons are now rulers; they are experiencing the passage of time and can no longer sing and dance in the same way. What started as a journey for merry-making in Goopy Gyne has now become not a pleasure trip or a desire to explore, learn and know. It has now become a path to temptation and perhaps even a path to ruin and destruction. They are prepared to sell their souls to the devil to gain more time on earth. Here the effervescence of the song "No, no, no more wastage of time" is replaced by a desperate clinging to life and a longing for youth.

What began as a funny tale by a gifted storyteller ended finally as a trilogy needing the work of three generations - a real triumvirate. It is fortunate that Satyajit trained his one and only son, Sandip in the art of movie making. As Barnouw points out:

The boy Sandip gradually became one of Satyajit Ray's most valued assistants - "the best assistant I ever had" - suggesting that the close family collaboration of past decades was continuing into a fourth generation. Satyajit had long treated Sandip as an adult, which seems to have been a Ray family tradition in the treatment of children - a key perhaps to their success of the children's magazine. (243)

As photographer and assistant director, Sandip learned a lot of things from his father that he could carry on after his father's death. And the greatest legacy to the Goopy Gyne Bagha Byne mythology is the story and the songs that Satyajit left behind, so that the project could finally be completed by his son. Satyajit loved making trilogies, as his very first venture, the $A p u$ trilogy shows; later on in his career, three generations contribute to a trilogy that proves again and again what can happen when masterminds come together. And

it is the fairy tale, that most broad and adaptable form of literature, which makes the collaboration so successful, because as it absorbs many elements, it transforms itself.

It is also significant that we have now witnessed the passing of the two actors; Robi Ghosh died many years ago and on May 24, 2010, Tapen Chatterjee, the legendary Goopy, died. Thus it makes us look with greater sorrow at the images of these actors. Will there ever be the likes of them again?

[Editor's note: An animated feature inspired by the Goopy and Bagha tales, directed by Indian filmmaker Shilpa Ranade, The World of Goopy and Bagha (Goopy gawaiya bagha bajaiya), was released in 2013.]

\section{References}

\section{Works Cited}

Barnouw, Eric and S. Kishnaswamy. Indian Film. New York: Oxford University Press, 1980.

Dworkin, Andrea. Woman Hating. New York: Dutton, 1974.

Kael, Pauline. For Keeps: 30 Years at the Movies. New York: Penguin, 1994.

Mukherjee, Sondwip. Wonder Tales of Upendrakishore Ray. Calcutta: Rupa, 1995.

Nyce, Ben. Satyajit Ray: A Study of his Films. New York: Praeger, 1988.

Ray, Sandip. Goopy Bagha Phire Elo. Calcutta: Government of West Bengal, 1991.

Ray, Satyajit. Goopy Gyne Bagha Byne. Calcutta: Purnima Pictures, 1968. 


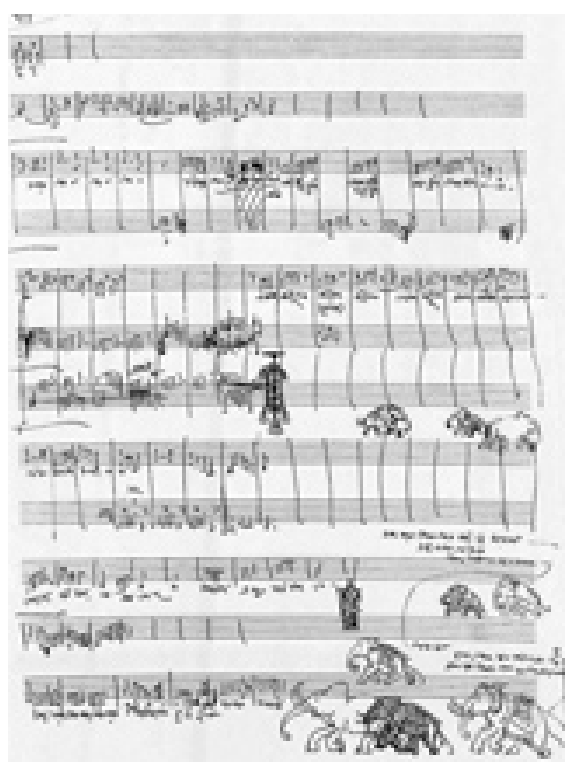

Figure 3: A sheet from Ray's musical score for Goopy Gyne Bagha Byne

- Hirak Rajar Deshe. Calcutta: Government of West Bengal, 1980.

. Our Films, Their Films. New Delhi: Orient Longman, 1976.

Ray, Sukumar. Abol Tabol. Transl. Sujoy and Chandana Chatterjee. http://www.aboltabol.freehostia.com/english.htm. Accessed 30 Sept. 2013.

Robinson, Andrew. Satyajit Ray: The Inner Eye. Calcutta: Rupa, 1990.

Sengoopta, Chandak. "Satyajit Ray: Liberalism and its Vicissitudes." Cineaste 34 (2009): 16-22.

Seton, Marie. Portrait of a Director: Satyajit Ray. Bloomington: Indiana University Press, 1971.

Vineberg, Steve. "Home and the World: Reflections on Satyajit Ray." The Threepenny Review 43 (1990): 3335 .

Zipes, Jack. Why Fairy Tales Stick: The Evolution and Relevance of a Genre. New York: Routledge, 2006.

\section{Author Information}

BANSARI MITRA (PhD SUNY, Buffalo) teaches at Clark Atlanta University. She specializes in British and Postcolonial Literature. Her book The Renovation of Folktales by Five Modern Bengali Writers examines inter-cultural influences and the migration of Western fairy tales to the East. 